\title{
SMALLHOLDER FOOD CROP FARMERS' PARTICIPATION IN BANK OF AGRICULTURE (BOA) LOAN SCHEME IN OGUN STATE, NIGERIA
}

\author{
${ }^{1}$ Adeoye S.O and 2 Ugalahi U.B. \\ ${ }^{1}$ Federal University of Agriculture, P.M.B 2240, Abeokuta, Nigeria \\ 2Department of Planning, Monitoring and Evaluation, National Cereals Research Institute, \\ Badeggi, P.O. Box 8 Bida, Niger State, Nigeria \\ Corresponding Author's Email, samadeoyeola@yahoo.com; Phone No: +2348034442577
}

\section{ABSTRACT}

Low participation of smallholder farmers in agricultural loans, despite efforts by governments and NGOs to make funds available for agricultural growth and development, has remained a matter of concern in Nigeria. The study analysed smallholder food crop farmers' participation in Bank of Agriculture loan (BOA) scheme in Ogun State, Nigeria. Data were analysed for 224 smallholder food crop farmers using simple percentages, means and Probit regression. Results revealed that the mean age, years of education and household size of farmers participating in the premier financial institution's loan scheme were 42 years, 13 years and 5 persons, respectively. Non-participants had mean age of 43 years, 9 years of education and household size of 7 persons, on average. Male farmers dominated on-farm food crop farming activities as $80 \%$ and $88 \%$ of participants and non-participants of the loan scheme, respectively were men. The study further showed the determinants of BOA loan scheme participation as: education level $(p<0.01)$, farm size $(p<0.01)$ extension visits $(p<0.05)$ and farmers' households distance to nearest BOA office $(p<0.01)$. Contrary to expectation, membership of farmers association had negative but no significant effect on loan participation. The study concluded that intensifying adult education programmes, increasing the number of branches of $B O A$ and promoting frequency of extension visits are crucial to achieving an increased probability of smallholder farmers' participation in BOA loan scheme.

Keywords: Bank of Agriculture, smallholder farmers, loan participation, Probit regression, Nigeria 


\section{INTRODUCTION}

Agricultural credit financing has been identified as a means of transforming the agricultural sector and revamping the Nigeria economy. However, the difficulty of smallholder farmers who produce more than $85 \%$ of domestic food supply to participate in agricultural credits/loans has remained a fundamental problem, despite the provision of financial aids by the government. Sub-Saharan African agriculture generally suffers this fate and this explains the socioeconomic characteristics of farmers and the nature and state of agricultural production across the African sub region (Adewunmi and Omotesho, 2002; Tchale, 2009; Omiti et al, 2009; Akinwale et al, 2016).

Smallholder farmers have limited access (ability and entitlement to borrow from a credit source) and/or participation (the actual borrowing) in credit/loan facilities (Diagne et al, 2001; Akramov, 2009; Okojie et al, 2010) thereby complain of inadequate production resources. Due to limiting financial conditions and failure to obtain loans from formal sources, farmers sometimes venture into borrowing from informal sources that charge exhorbitant interest rates- thus leaving them with a discouraging net farm income at the end of the production season. The meagre income made from farming undertaken is usually used in consumption smoothing leaving nothing for farm capital investment (Park et al, 2003; Sadiq et al, 2015).

Mgbakor et al, (2013) asserted that this situation causes capital constraints for productive activities, inability to increase production levels and also diminishes household risk bearing ability. As a result, the farmer is unable to upgrade from peasantry to large scale agriculture which is a most desired transition especially at this period of agricultural development efforts to increase self-sufficiency in food production and diversify the country's economy from its mono-commodity status.

A typical Nigerian farmer is indeed credit constrained (Omonona et al, 2010) and has difficulty in obtaining formal loans (Oluwasola and Alimi, 2007; Anyiro, 2015). These conditions (partly) explain the state of the nation's food crop production subsector (Lipton, 2013) and the current economic recession.

Statistical evidences suggest that the Nigerian economy needs urgent revamping to rescue it from recession. Unemployment rate has risen to $12.10 \%$ (with youth unemployment at $25 \%$ ), gross domestic product (GDP) by expenditure stands at $2.11 \%$, poverty rate at $61 \%$, inflation 
rate at $12.77 \%$ and food price index at $11.22 \%$ (Central Bank of Nigeria (CBN) 2016; National Bureau of Statistics (NBS) 2016).

Virtually all sectors of the economy are hobbled while risks and uncertainties are high. The inability of the country to attain self-sufficiency in food production has also taken its toll on the economy. The CBN reported annual food import to be over 630 Billion Naira (CBN 2015). This volume of food importation is alarming and retrograding to domestic agricultural production and foreign exchange. Development analysts have shown that for a sustainable growth in the economy, there must be a repositioning of the agricultural sector to a major revenue base of the country (Okojie et al, 2010; Okuneye and Ayinde, 2011; Agbonlahor et al, 2015).

The ability of a developed agricultural sector to revamp Nigeria's economy is evidenced in history: Agricultural sector prior to the advent of crude oil, contributed about $70 \%$ to Nigeria's GDP, employed about $70 \%$ of the population and made up $90 \%$ of foreign exchange earnings (Adedipe, 2004). Despite the neglect and irrational focus of government on oil, agriculture has remained the single largest non-oil contributor to the Nation's GDP (though currently below $30 \%$ ), employing more than two-third of the nation's active labour force, contributing to foreign exchange and providing raw materials for local industries (Oni et al, 2009; NBS 2017).

In a bid to develop the agricultural sector and achieve the corresponding benefits, Nigerian Government through its institutions has been providing support largely in the form of financial interventions to farmers. The focus on financial aid is not surprising since limited finance and credits are some of the major problems faced by the agricultural sector (Food and Agriculture Organisation (FAO), 2016). Moreover agricultural credit is believed to increase agricultural productivity as well as efficiency of land, water, capital and human resources (Carter, 1989; Siddiqi et al, 2004; Okulegu et al, 2014).

Nigeria has embarked on a series of sector specific financial interventions in the form of micro credit schemes/programmes and development finance institutions (DFI) to help improve the productivity and livelihood of the poor (CBN 2005) who are predominantly rural farmers. Notable among the agriculture specific institutions was the Nigerian Agricultural Bank (NAB) established in 1973. Through a series of policy changes, restructuring and merger of notable financial institutions in the country, NAB's nomenclature has changed over the years and evolved into the Bank of Agriculture (BOA) Limited in 2010. Given the several years of restructuring and its premier agricultural financial institution status in the country, BOA is 
expected to provide services that guarantees the financially less privileged farmer the opportunity of participating in its loan scheme.

Nevertheless, as government strive to promote agricultural development through credit provision obtainable from BOA (Olagunju and Adeyemo, 2008), farmers' continued resource limitation and failure to participate in the loan scheme call for concern. Between December 2016 and May 2017 the BOA disclosed making over 23 Billion Naira available for farmers as part of its agricultural development efforts. But are the smallholder (rural) farmers- the 'real food crop producers' able to participate in this fund?

Agricultural financial analysts believe that many times, it is not the lack or insufficiency of credit facility that is a major problem. But rather that the farmer is sometimes not poised to benefiting from available credit due to certain socioeconomic constraints such as level of education, accessibility to financial institution, farm size, membership of associations, contact with extension agents, and so on (Akramov, 2009; Essien and Arene, 2014; Anang et al, 2015; Agbo et al, 2015).

A detailed analysis of food crop farmers' participation in BOA loans was thus conducted to complement existing literature and also provide information for operators of Bank of Agriculture in Nigeria, similar financial institutions in the country as well as agricultural credit policy makers in designing more effective and sustainable agricultural loan schemes. The study examined the socioeconomic characteristics of participating and non-participating smallholder food crop farmers in BOA loans and determined factors that influence the probability of participation in BOA loans in Ogun State, Nigeria.

\section{METHODOLOGY}

\section{Study Data}

The study was conducted using primary data drawn with the use of structured questionnaire from participating and non-participating smallholder food crop farmers in BOA loan scheme in Ogun State, southwest Nigeria. The characteristics used to describe smallholders in the context of the study include: utilisation of family labour, restricted access to inputs and outputs markets, limited financial capacity and use of rudimentary technology (Lipton, 2013; United Nations Conference on Trade and Development (UNCTAD) 2015). Most of the farmers practice mixed cropping; generally grouped as cassava based or yam based depending on whether cassava or yam is the major crop grown. The study area has an 
abundance of cassava based (growing mainly cassava, and other food items like maize, vegetables, cowpea, and so on.) farmers, and are thus chosen as representatives of food crop farmers. The state has four Agricultural Development Programmes (ADP) zones across its 20 Local Government Areas (LGAs). The BOA has eight branch offices- two in each ADP zone. Ambali et al, (2012) itemised the zones and communities in which the BOA branch offices are located.

\section{Sampling and Analytical Techniques}

The food crop farmers were drawn in a multistage sampling technique. The first stage was a purposive selection of four blocks (one in each ADP zone) reputed for high food crop production intensity. The second stage comprised a random selection of two cells from each of the (four) selected blocks. The third stage involved independent random selection of participating and non-participating farmers; 14 participating farmers from each of the eight selected cells were randomly selected from a list obtained from BOA office and were contacted and 14 non-participants were also randomly selected from the same cells from a population generated through farmers associations and community heads. A total number of 224 food crop farmers were surveyed for the study. Simple percentages were used to describe the socioeconomic characteristics of the food crop farmers while Probit regression was used to analyse the determinants of smallholder food crop farmers' participation in BOA loan scheme.

\section{Specification of the Probit Model}

The binary Probit regression being a choice probability model (Greene, 2012) was specified for the estimation of the determinants of food crop farmers' participation in BOA loan. The model assumes a latent variable $\mathrm{y}^{*}$, which represents the utility index I, defined for individual food crop farmer t, as:

$$
I_{t}=X_{t}^{\prime} \beta \text { or } y_{t}^{*}=X_{t}^{\prime} \beta
$$

$\beta$ is the parameter to be estimated and $X$ is the vector of explanatory variables. The error term, $e$ of the model is assumed to follow a standard normal distribution with a mean of zero and variance of one. Hence, it is explicitly specified as:

$$
y_{t}^{*}=X_{t}^{\prime} \beta+e_{t}, e_{t} \sim N[0,1]
$$


Since $y^{*}$ is unobservable, there is a threshold utility level in that, if $y^{*}$ exceed zero the crop farmer participates in the loan, otherwise he/she does not participate.

$$
y_{t}=1 \text {, if } y_{t}^{*}>0 \text {, otherwise } y_{t}=0
$$

The utility index which ranges between negative infinity and positive infinity $(-\infty$ to $+\infty)$ is usually translated to the range of 0,1 by the use of a cumulative distribution function so that

$$
\begin{aligned}
& P(Y=1)=P_{t}=F\left(y_{t}\right)=F\left(X_{t}^{\prime} \beta\right)=\frac{1}{\sqrt{2 \pi}} \int_{-\infty}^{I} \exp \left(\frac{-t^{2}}{2}\right) d t= \\
& \frac{1}{\sqrt{2 \pi}} \int_{-\infty}^{X_{t}^{\prime} \beta} \exp \left(\frac{-t^{2}}{2}\right) d t
\end{aligned}
$$

The model specified for BOA loan participation is thus expressed as follows

$$
Y_{t}=\beta_{0}+\beta_{1} X_{1 t}+\beta_{2} X_{2 t}+\beta_{3} X_{3 t}+\cdots \beta_{n} X_{n t}+e_{t}
$$

Where $Y_{t}$ is the binary dependent variable which represents smallholder food crop farmer that participates or do not participate in $B O A$ loan. $X_{t}$ is the vector of independent variables that influences crop farmers' participation and $e_{t}$ is the random and normally distributed error term.

\section{Definition of the Variables}

The explanatory variables estimated in the probability of participation model are: Age of farmer $\left(X_{1}\right)$ - measured in completed years; Education level $\left(X_{2}\right)$ - the number of successful years of schooling, not taking into account year(s) of repeated classes; Household size $\left(X_{3}\right)$ number of persons living under the same roof and sharing common cooking arrangements with the farmer at the time of the survey; Membership of farmers association ( $\left.\mathrm{X}_{4}\right)$ - dummy variable, 1 if farmer is a member of farmers group/association, 0 otherwise; Farm size $\left(X_{5}\right)$ the area of farmland in hectares cultivated by the farmer; Distance to nearest BOA office $\left(X_{6}\right)$ distance in kilometres of the farmer's household to the nearest BOA office; Extension visit $\left(X_{7}\right)$ - frequency of visit of extension agents to the farmer. 


\section{RESULTS AND DISCUSSION}

\section{Characteristics of the Farmers}

Table 1 shows the socioeconomic characteristics of food crop farmers. The table reveals $35-$ 44 years as the modal age range $(48.2 \%)$ of the food crop farmers that participate in BOA loan, whereas the modal age range (43.8\%) of the non-participating farmers was $45-54$ years. The mean age for participating farmers was 42 years, and 43 years for nonparticipants. The mean age shows that the food crop farmers were within the productive age.

Male farmers constituted about $80 \%$ and $88 \%$ of participating and non-participating farmers, respectively. This result shows the dominance of men in on-farm food crop production activities in the study area. Participating farmers had relatively higher level of formal education than their non-participating counterparts with an average of 13 years as compared to nine years observed among non-participants. Although both categories of farmers had $10-$ 12 years (senior secondary education experience) as the modal education level range; $81.5 \%$ for participants and $55.0 \%$ for non-participants. As shown in Table 2, none of the participating farmers had household size larger than 16 persons whereas up to $7.4 \%$ of non-participating farmers had household size exceeding 16 persons. The mean household sizes for participating and non-participating farmers are five and seven individuals, respectively.

Majority of the non-participating farmers $(67.9 \%)$ cultivate farm sizes of $1-1.5$ ha which is relatively lower than the proportion of participants that cultivates larger farm sizes. About $10 \%$ of participating farmers and $3 \%$ of non-participating farmers cultivates 2.5 - 3ha of farmland. On average, participating farmers cultivate $1.8 \mathrm{ha}$ of farmland while non-participating farmers cultivate $1.2 \mathrm{ha}$. Years of farming experience of participating and non-participating farmers are similar, on the average. 
Table 1: Socioeconomic characteristics of food crop farmers $(N=224)$

\begin{tabular}{lll}
\hline Characteristic & \multicolumn{2}{c}{ Distribution (\%) } \\
& Participants & Non-participants \\
\hline Age & 14.3 & 9.8 \\
$<35$ & 48.2 & 38.4 \\
$35-44$ & 27.7 & 43.6 \\
$45-54$ & 9.8 & 7.1 \\
$55-64$ & - & 1.1 \\
$>65$ & 42.47 & 43.45 \\
Mean & & \\
Sex & 80.4 & 87.5 \\
Male & 19.6 & 12.5 \\
Female & & \\
Education level & 5.8 & 36.1 \\
$\leq 6$ & 12.1 & 6.7 \\
$7-9$ & 81.2 & 55.0 \\
$10-12$ & 0.9 & 2.2 \\
$>12$ & 12.70 & 8.85 \\
Mean & &
\end{tabular}

Source: Field survey, 2015 
Table 2: Socioeconomic characteristics of food crop farmers, contd.

\begin{tabular}{|c|c|c|}
\hline \multicolumn{3}{|c|}{ Household size } \\
\hline$<5$ & 27.5 & 24.1 \\
\hline $5-10$ & 67.5 & 64.1 \\
\hline $11-16$ & 5.00 & 4.5 \\
\hline $17-22$ & - & 4.5 \\
\hline$>22$ & - & 2.7 \\
\hline Mean & 5.39 & 6.95 \\
\hline \multicolumn{3}{|c|}{ Farm size } \\
\hline$<1.0$ & 21.4 & 19.6 \\
\hline $1-1.5$ & 20.5 & 67.9 \\
\hline $1.6-2.0$ & 15.2 & 9.8 \\
\hline $2.1-2.5$ & 33.0 & - \\
\hline $2.5-3$ & 9.8 & 2.7 \\
\hline Mean & 1.83 & 1.23 \\
\hline \multicolumn{3}{|c|}{ Farming experience } \\
\hline$<5$ & 19.6 & 15.2 \\
\hline $5-10$ & 43.8 & 39.3 \\
\hline $11-16$ & 19.6 & 36.6 \\
\hline $17-22$ & 11.6 & 6.3 \\
\hline$>22$ & 5.4 & 2.7 \\
\hline Mean & 9.97 & 9.93 \\
\hline
\end{tabular}

Source: Field survey, 2015 


\section{Probability of BOA Loan Participation}

The factors influencing the probability of BOA loan participation is shown in Table 3 . The likelihood ratio test of the estimated Probit regression is 152.370 and is highly significant at the 0.01 level. This suggests the specified Probit model well fits the data and significantly explains the effect of the estimated variables on food crop farmers' participation in BOA loans when compared to an empty model. Estimation results show that education level of farmer, farm size, distance to nearest BOA office are significant at the 0.01 level and extension visits is significant at the 0.05 level in the probability of farmers' participation in BOA loans.

Level of education has a positive and significant effect on the probability of participation in BOA loans. This implies that the probability of participation increases as the years of education increases. The estimated marginal effect $(\mathrm{dy} / \mathrm{dx})$ reveals that one year increase in the farmer's education will raise the probability of participation by $4.6 \%$, on average. This shows the importance of education in creating awareness and knowledge of the benefits of and how to secure farm credits (Anyiro and Oriaku, 2011).

Contrary to expectation, a negative coefficient on membership of farmers' association is observed, though not significant. This inverse relationship between membership of association and loan participation may be attributed to the reported moribundity of most of the farmers' groups by the smallholders during the survey.

A direct and significant relationship is found between farm size and BOA loan participation. A hectare increase in farm size resulted in a $30 \%$ increase in the probability of loan participation. Large farm size normally suggests to loan providers that the farmer would possess the ability to manage loan as well as risks and uncertainties, thereby creating a perception of credit worthiness for large farm owners. 
Table 3: Probit estimations of BOA loan participation

\begin{tabular}{lllll}
\hline Variable & Coefficient & Std. Err. & z-value & dy/dx \\
\hline Age & 0.028 & 0.019 & 1.430 & 0.011 \\
Education & $0.115^{* * *}$ & 0.033 & 3.460 & 0.046 \\
Household size & -0.031 & 0.052 & -0.600 & -0.012 \\
Membership of farmers association & -0.412 & 0.279 & -1.470 & -0.162 \\
Farm size & $0.754^{* * *}$ & 0.166 & 4.550 & 0.300 \\
Distance to nearest BOA office & $-0.252^{* * *}$ & 0.043 & -5.900 & -0.100 \\
Extension visits & $0.503^{* *}$ & 0.100 & 5.020 & 0.200 \\
Constant & $-2.356^{* *}$ & 1.060 & -2.220 & \\
Sample size & 224.000 & & & \\
LR chi2(7) & 152.370 & & & \\
Prob > chi2 & 0.0000 & & & \\
Log likelihood & -79.082 & & & \\
PseudoR2 & 0.491 & & & \\
\hline Source; Field & & & & \\
\hline
\end{tabular}

Source: Field survey, 2015

${ }^{* * *},{ }^{* *},{ }^{*}$ indicate significant levels at $1 \%, 5 \%$ and $10 \%$, respectively 
Moreover, larger farm size serves as a push factor to farmers to seek financial assistance in order to put resources to optimum use. The result is consistent with the finding of a similar study by Asogwa and Ocheche (2011) in Benue State, Nigeria.

There is an inverse and significant relationship between participation in BOA loan and the distance of the farmers' households to the nearest BOA office. Farmers whose households were farther from the nearest BOA office tended to participate less in the loan scheme. The probability of loan participation decreases by $10 \%$ for every kilometre increase in distance from the farmers' households to the nearest BOA office. Hence, distance accessibility is an important factor influencing loan participation among smallholder food crop farmers in the study area. The finding affirms outcome of the analysis of a Vietnam data where distance to credit source is found to be a significant factor (Nguyen, 2007).

Frequency of extension visits to food crop farmers is positive and significant to the probability of BOA loan participation. The higher the number of times farmers were visited the higher their chances of participation. The probability increased by $20 \%$ for a unit increase in extension visits. This outcome is consistent with popular findings that extension services provide farmers with latest education on farm technology and information that could enhance farmers operations. Anang et al, (2015) in their study of Northern Ghana found similar result.

\section{CONCLUSION AND RECOMMENDATIONS}

The study analysed the participation of smallholder food crop farmers in BOA loans scheme. Results revealed that the food crop farmers are- within their productive age, mostly males and have approximately the same years of farming experience. However, participating farmers in BOA loan scheme tend to differ from their non-participating counterparts in terms of education level, cultivated farm size and household size. Factors that determine the probability of farmers' participation in BOA loan are education of the farmer, farm size, distance to nearest BOA office and frequency of extension visits.

The study concludes that education, farmers' proximity to BOA offices and extension visits are crucial to improving the probability of smallholder food crop farmers' participation in BOA loans. Therefore, the following recommendations are made: Government and NGOs should intensify efforts on adult education programmes with focus on smallholder food crop farmers; Bank of Agriculture should open more branch offices in the food crop farming communities 
such that BOA offices are closer to the farmers; The Bank and relevant policy makers should work on an extension service delivery that ensures regular contacts with the farmers.

\section{REFERENCES}

Adedipe, B. (2004): The Impact of Oil on Nigeria's Economic Policy Formulation. Paper Presented at the Conference on Nigeria: Maximising Pro-Poor Growth; Regenerating The Socioeconomic Database. Overseas Development Institute and Nigerian Economic Summit Group16th-17th June, 2004.

Adewunmi, M.O. and Omotesho, O.A. (2002): "An Analysis of Production Objectives of Small Scale Rural Farming Household in Kwara State, Nigeria". Journal of Rural Development Korea. 25:201-21.

Agbo, F.U., Iroh, I.I. and Ihemezie, E.J. (2015): "Access to Credit by Vegetable Farmers in Nigeria: A Case Study of Owerri Agricultural Zone of Imo State, Nigeria". Asian Journal of Agricultural Research. 9(4): 155-165.

Agbonlahor, M.U., Adewuyi, S.A. and Ogundairo, V.O. (2015): "Do Rural Smallholder Farmers Subsidize Farm Investments with Non-farm Income? A Study of Vegetable Farmers". International Journal of Vegetable Science. 22: 231-242.

Akinwale, J.A., Ladele, A.A. and Olajide, B.R. (2016) :"Yield Differentials among Participating and Non-participating Rice Farmers in Public/Private Partnership in Benue and Ogun States, Nigeria". Agrosearch. 16(1): 23-37.

Akramov, K.T. (2009): "Decentralization, Agricultural Services, and Determinants of Input Use in Nigeria". Discussion Paper 941. Washington, D. C.: International Food Policy Research Institute.

Ambali, O.I., Adegbite, D.A., Ayinde, I.A. and Idowu, A.O. (2012): "Analysis of Production Efficiency of Food Crop Farmers of Bank of Agriculture Loan Scheme in Ogun State, Nigeria". Asian Journal of Agricultural Sciences. 4(6): 383-389.

Anang, B.T., Sipilainen, T., Backman, S. and Kola, J. (2015): "Factors Influencing Smallholder Farmers' Access to Agricultural Microcredit in Northern Ghana". African Journal of Agricultural Research. 10(24): 2460-2469. 
Anyiro, C.O. and Oriaku, B.N. (2011): "Access to and Investment of Formal Micro Credit by Smallholder Farmers in Abia State, Nigeria. A Case Study of ABSU Microfinance Bank, Uturu". The Journal of Agricultural Sciences. 6(2): 69-76.

Anyiro, C.O. (2015): "The Effect of Social Capital on Access to Micro Credit among Rural Farming Households in Abia State, Nigeria. Agrosearch. 15(1): 59-75.

Asogwa, B.C., Abu, O. and Ocheche, G.E. (2014): "Analysis of Peasant Farmers' Access to Agricultural Credit in Benue State, Nigeria". British Journal of Economics, Management and Trade. 4(10): 1525-1543.

Carter, M.R. (1989): "The Impact of Credit on Peasant Productivity and Differentiation in Nicaragua". Journal of Development Economics. 31(1): 13-36.

CBN (2005): Central Bank of Nigeria: Annual Report and Financial Statements.

CBN (2015:) Central Bank of Nigeria Annual Report 2015.

CBN (2016): Inflation Rates. Available at https://www.cbn.gov.ng/rates/inflrates.asp (Accessed on 25 June 2016).

Diagne, A., Zeller, M. and Sharma, M. (2001): Empirical Measurement of Households' Access to Credit and Credit Constraints in Developing Countries: Methodological Issues and Evidence. FCND Discussion Paper, No. 90, IFPRI, Washington DC.

Essien, U.A . and Arene, C.J. (2014): "An Analysis of Access to Credit Markets and the Performance of Small Scale Agro-Based Enterprises in the Niger Delta Region of Nigeria. International Journal of Food and Agricultural Economics. 2(3): 105-120.

FAO (2016): Nigeria at a Glance. Available at www.fao.org/nigeria-at-a-glance/en (Accessed on 01July 2016)

Greene, W.H. (2012): Econometric Analysis. Seventh Edition. Upper Saddle River, N.J: Prentice Hall.

Lipton, M. (2013): Staples Production: 'Efficient Subsistence' Smallholders are Key to Poverty Reduction, Development and Trade. Paper Presented at the Global Commodities Forum, UNCTAD, 18-19 March, Geneva, 2013. 
NBS (2016) Key Indicators. Available at http://www.nigerianstat.gov.ng/ (Accessed on 25 June 2016).

NBS (2017): Nigerian Gross Domestic Product Report, Quarter Four 2016.

Nguyen, C.H. (2007): Access to Credit and Borrowing Behaviour of Rural Households in a Transition Economy. International Conference on Rural Finance Research: Moving Results into Policies and Practice. Centre for Economic Reform and Transformation, Heriot-Watt University, Edinburg, UK.

Okojie, C., Monye-Emina, A., Eghafona, K., Osaghae, G. and Ehiakhamen, J.O. (2010): Institutional Environment and Access to Microfinance by Self-Employed Women in the Rural Areas of Edo State. NSSP Brief No. 14. International Food Policy Research Institute: Washington. D.C.

Okulegu, B.E., Onwe, O.G. and Okoro, O.T. (2014): "Banking Sector Credit and Performance of the Agricultural Sector in Nigeria (1981-2011)". Global Journal of Applied Management and Social Sciences. 7:35-55.

Okuneye, P.A. and Ayinde, I.A. (2011): "The Nigerian Agricultural Policy Inadequacy: The Way Forward". Nigerian Journal of Agricultural Economics. 2(1): 1-119.

Olagunju, F.I. and Adeyemo, R. (2008): "Evaluation of the Operational Performance of the Nigerian Agricultural Credit Cooperative and Rural Development Bank (NACRDB) in South-Western Nigeria". International Journal of Agricultural Economics and Development. 1(1): 53-67.

Oluwasola, O. and Alimi T. (2007): "Financial Intermediation in Agriculture in Nigeria: Emerging Role of Non-Governmental Organisations (NGOs). Agrosearch. (1\&2): 43-51.

Omiti, J.M., Otieno, D.J., Nyanamba, T.O. and Mccullough, E. (2009): "Factors Influencing the Intensity of Market Participation by Smallholder Farmers: A Case Study of Rural and Peri-Urban Areas of Kenya". African Journal of Agricultural and Resource Economics. 3(1): 57-82. 
Omonona, B.T., Lawal, J.O. and Oyinlana, A.O. (2010): "Determinants of Credit Constraint Conditions and Production Efficiency among Farming Households in Southwestern Nigeria". The Social Sciences. 5(4): 326-331.

Oni, O., Nkonya E, Pender, Philips, D. and Kato E. (2009): Trends and Drivers of Agricultural Productivity in Nigeria. Nigeria Strategy Support Program (NSSP) Report 001, IFPRI: Abuja, Dec. 200934 pp.

Park, A., Brandt, L. and Giles, J. (2003): "Competition under Credit Rationing: Theory and Evidence from Rural China". Journal of Development Economics. 71(2): 463-495

Sadiq, M.M., Kolo, M.D. and Akerele, F.O. (2015): "Determinants of Credit Constraints of Farming Households Participating in National Special Programme for Food Security (NSPFS) in Niger State, Nigeria". Global Journal of Agricultural Economics and Econometrics. 3(1): 114-120.

Siddiqi, M.W. Mazhar-Ul-Haq. and Baluch, K.N. (2004): "Institutional Credit: A Policy Tool for Enhancement of Agricultural Income of Pakistan. International Research Journal of Arts and Humanities. 37:157-174.

Tchale, H. (2009): "The Efficiency of Smallholder Agriculture in Malawi". African Journal of Agricultural and Resource Economics. 3(2): 101-121.

UNCTAD (2015): Smallholder Farmers and Sustainable Commodity Development. Commodities and Development Report, New York and Geneva: United Nations Conference on Trade and Development. 